\title{
Isoamylene Oligomerization over Zeolite Catalysts
}

\author{
N. G. Grigor'eva ${ }^{a, *}$, D. V. Serebrennikov ${ }^{a}$, S. V. Bubennov ${ }^{a}$, and B. I. Kutepov ${ }^{a}$ \\ ${ }^{a}$ Institute of Petroleum Chemistry and Catalysis, Russian Academy of Sciences, Ufa, 450075 Russia \\ *e-mail:ngg-ink@mail.ru
}

Received June 5, 2020; revised October 20, 2020; accepted November 5, 2020

\begin{abstract}
The study of isoamylene oligomerization over a number of microporous zeolites such as $\mathrm{H}-\mathrm{Y}$, H-MOR, H-Beta, H-ZSM-12, and H-ZSM-5 revealed that the isoamylene conversion rate decreases in the following order: $\mathrm{H}-\mathrm{MOR}>\mathrm{H}-\mathrm{Y}>\mathrm{H}-\mathrm{Beta}-40>\mathrm{H}-\mathrm{ZSM}-12>\mathrm{H}-\mathrm{ZSM}-5$. The maximum yields of isoamylene oligomers were achieved by using H-MOR (85.0\%), H-Y (80.1\%), and H-Beta-40 (79.8\%). The predominant isoamylene oligomers are dimers regardless of the zeolite catalyst used. The trimer yield reaches its highest when wide-pore zeolites like H-MOR, H-Y, or H-Beta-40 are employed. An increase in the number of acid sites enhances monomer conversion rate, oligomer yield, and oligomer molecular weight. Conditions for producing isopentene dimers and trimers with the maximum possible yield were determined.
\end{abstract}

Keywords: isoamylene, oligomerization, dimers, trimers, isomerization, cracking, zeolites

DOI: $10.1134 / \mathrm{S} 096554412102002 \mathrm{X}$

Oligomerization of light alkenes is a promising solution for producing higher-molecular-weight compounds for use as engine fuel components [1]. Silica-phosphate systems, which are the most common industrial catalysts for oligomerization of lower $\left(\mathrm{C}_{3}-\mathrm{C}_{4}\right)$ olefins [2], have serious disadvantages such as short lifetime, complications in their removal from the reactor and disposal, and equipment corrosion. More state-ofthe-art lower-olefin oligomerization processes employ ZSM-5 based catalysts (Mobil Oil MOGD process) [3].

Isoamylene oligomerization has been the least explored for lower $\left(\mathrm{C}_{3}-\mathrm{C}_{5}\right)$ olefins. Many studies on isoamylene oligomerization utilized cation-exchange resins such as Amberlyst, Pyrolite, or Nafion [3-10]. Some earlier papers [3-7] report attempts at selective production of dimers, driven by the following: (1) isoamylene dimers have a high octane number (specifically, the research octane number is 96, and even reaches 105 after hydrogenation), thus representing an option alternative to isooctane; and (2) amylene dimerization is a method to decrease the light naphtha vapor pressure and thus reduce $\mathrm{C}_{5}$ emissions, because the high reactivity of amylenes enables them to largely contribute to the tropospheric ozone formation [4]. Dimerization of isoamylenes in the presence of cation exchange resins occurs under relatively mild conditions $\left(60-100^{\circ} \mathrm{C}\right.$, autoclave pressure up to $2 \mathrm{MPa}$ ) with the formation of primarily isodecenes (at least 90\%). It was found that isodecene selectivity can be improved up to $97 \%$ by adding low-molecular alcohols, although this gives rise to esterification byproducts.

The recently increasing demand for diesel fuel has stimulated Granollers et al. [8] to study isoamylene trimerization in the presence of cation exchange resins. Catalysts with a high degree of polymer framework crosslinking and high acidity are the most active [10]. The trimer yield over Amberlyst 15, the best of the explored resins, reaches $45-50 \%$.

Given the well-known disadvantages of cation exchange resins (such as low thermostability and irreversible deactivation under elevated temperatures or when contaminants are present in the reaction mixture), the search for effective heterogeneous catalysts for isoamylene oligomerization continues.

There have been few studies devoted to oligomerization of amylenes (or amylene-containing fractions) over zeolite catalysts $[8,11-13]$. These studies generally dealt with the conversions of catalytic-cracking-derived light naphtha primarily over ZSM-5, which is the main component of the MOGD process catalyst. In addition to the ZSM-5 pentasyl zeolite, other zeolites such as BEA, Ni-BEA, and MOR have also been tested [11]. It should be noted that the researchers were easily able to attain a sufficiently high degree of 2-methylbut-2-ene conversion, 
Table 1. Isoamylene composition ${ }^{\mathrm{a}}$

\begin{tabular}{c|c|c|c|c|c|c|c|c|c|c}
\hline Hydrocarbons & iso-P & $3 \mathrm{MB} 1$ & $n$-P & $\mathrm{P} 1$ & $2 \mathrm{MB} 1$ & $E$-P2 & $Z$-P2 & $2 \mathrm{MB} 2$ & IP & $\sum$ olefins \\
\hline Concentration, wt \% & 1.7 & 2.9 & 9.4 & 0.8 & 28.0 & 2.7 & 1.3 & 52.4 & 0.8 & 88.9 \\
\hline
\end{tabular}
(iso-P) isopentane; (3MB1) 3-methylbut-1-ene; (n-P) n-pentane; (P1) pent-1-ene; (2MB1) 2-methylbut-1-ene; (E-P2) trans-pent-2-ene; (Z-P2)
cis-pent-2-ene; (2MB2) 2-methylbut-2-ene; and (IP) isoprene.

so they were rather focused on the conversion of pent-1ene, which proved to be much more inert.

In trimerization of isoamylenes over zeolite catalysts (H-BEA-25, H-FAU-6, H-FAU-30, and H-MOR-20) [8], H-FAU-30 demonstrated a high trimer selectivity of $45 \%$ at $98 \%$ isoamylene conversion. Dimers were most selectively produced over H-BEA-25 and H-MOR-20.

In view of the relevance of studies on the oligomerization processing of amylenes into environmentally friendly fuel components, and given the paucity of research on catalytic properties of zeolites in this reaction, we have systematically examined isoamylene oligomerization over microporous zeolites of various structure types, such as FAU (Y), MOR, BEA (Beta), MTW (ZSM-12), and MFI (ZSM-5) in the $\mathrm{H}-$-form, and reported the results in this paper.

\section{EXPERIMENTAL}

In the reported study, we used a $\mathrm{C}_{5}$ hydrocarbon fraction provided by the Sintez-Kauchuk Plant in Sterlitamak city, Republic of Bashkortostan, Russia. Its composition is presented in Table 1. The initial mixture was mainly composed of 2-methylbut-2-ene (52.4\%) and 2-methylbut-1-ene (28.0\%).

$\mathrm{Na}-\mathrm{Y}\left(\mathrm{SiO}_{2} / \mathrm{Al}_{2} \mathrm{O}_{3}=5\right)$ and $\mathrm{Na}-\mathrm{ZSM}-5\left(\mathrm{SiO}_{2} / \mathrm{Al}_{2} \mathrm{O}_{3}=\right.$ 40) were synthesized in the Ishimbay Specialized Chemical Catalyst Plant, Republic of Bashkortostan, Russia, and $\mathrm{H}-\mathrm{ZSM}-12\left(\mathrm{SiO}_{2} / \mathrm{Al}_{2} \mathrm{O}_{3}=34\right)$ and $\mathrm{NH}_{4}$-Beta $\left(\mathrm{SiO}_{2} / \mathrm{Al}_{2} \mathrm{O}_{3}=18\right)$ in the Angarsk Catalyst and Organic Synthesis Plant, Irkutsk Region, Russia. Na-MOR $\left(\mathrm{SiO}_{2} / \mathrm{Al}_{2} \mathrm{O}_{3}=16\right)$ was acquired from Clariant International and $\mathrm{NH}_{4}$-Beta $\left(\mathrm{SiO}_{2} / \mathrm{Al}_{2} \mathrm{O}_{3}=40\right)$ from Zeolyst International. The Na-forms of zeolite samples were transferred to the $\mathrm{H}$-forms through ion exchange in an $\mathrm{NH}_{4} \mathrm{NO}_{3}$ solution followed by atmospheric heat treatment at $540^{\circ} \mathrm{C}$ for $4 \mathrm{~h}$. The Y-zeolite samples with decationation degrees $(\alpha)$ of 0.62 and 0.93 that were thus obtained are referred to herein as $0.62 \mathrm{NaH}-\mathrm{Y}$ and $0.93 \mathrm{H}-\mathrm{Y}$, respectively. The $\mathrm{NH}_{4}$-forms of Beta zeolites $\left(\mathrm{SiO}_{2} / \mathrm{Al}_{2} \mathrm{O}_{3} 18\right.$ and 40$)$ were transferred to the $\mathrm{H}$-forms by atmospheric heat treatment at $540^{\circ} \mathrm{C}$ for $4 \mathrm{~h}$.

Prior to catalytic testing, the zeolite samples were subjected to atmospheric heat treatment at $540^{\circ} \mathrm{C}$ for $4 \mathrm{~h}$.
The chemical composition of the zeolite samples was tested by X-ray fluorescence spectrometry on a Shimadzu EDX-720/900HS instrument. The phase composition of the samples was determined by a template matching technique on a Bruker D8 Advance diffractometer with monochromated $\mathrm{Cu} K_{\alpha}$ radiation. Data collection was carried out in the $2 \theta$ range of $5^{\circ}$ to $40^{\circ}$, with a step of $0.5^{\circ}$ per minute and counting time of $20 \mathrm{~s} / \mathrm{step}$. The relative crystallinity was calculated as a ratio of the total integral intensity of the crystalline phase to the total integral intensity of the crystalline and amorphous phases.

The particle sizes in the test samples were determined by diffraction (scattering) of laser light $(\lambda=680 \mathrm{~nm})$ on a Fritsch Analysette 22 NanoTec instrument.

The equilibrium adsorption capacity of zeolites for water and benzene vapors was determined at $23-25^{\circ} \mathrm{C}$ and $P / P s=0.80-0.85$ using a desiccator method based on measuring the total zeolite saturation with adsorbate vapors.

The acidic properties of the zeolite samples were examined by temperature-programmed desorption (TPD) of ammonia.

Oligomerization was carried out in continuously rotating autoclaves within a temperature range of $60-200^{\circ} \mathrm{C}$. The zeolite catalyst's weight content was $10-30 \%$ in an olefin equivalent. After the experiment, the liquid-nitrogen-cooled reaction mixture was filtered from the catalyst and divided into an amylene fraction and an oligomer fraction. The amylene fraction was tested by gas chromatography on a Crystal-Lux 4000M instrument equipped with a thermal conductivity detector (6 m packed column, 20\% dibutyl phthalate/diatomaceous earth phase). The oligomers were tested by GLC on a Carlo Erba HRGS 5300 Mega Series chromatograph equipped with a flame ionization detector $(25 \mathrm{~m}$ glass capillary column, SE-30 phase), and by high performance liquid chromatography on a Shimadzu LC-20 Prominence instrument equipped with a refractometric detector and a Plgel 500Å polystyrene column.

The products were identified by chromatographymass spectrometry, IR, ${ }^{1} \mathrm{H}$ and ${ }^{13} \mathrm{C}$ NMR spectroscopy, and ${ }^{13} \mathrm{C}$-DEPT. IR spectra were recorded on a VERTEX 
Table 2. Physicochemical properties of zeolite samples ${ }^{\mathrm{a}}$

\begin{tabular}{|c|c|c|c|c|c|c|c|c|}
\hline \multirow{2}{*}{ Sample } & \multirow{2}{*}{ Crystallinity, $\%$} & \multirow{2}{*}{$\begin{array}{l}\mathrm{SiO}_{2} / \mathrm{Al}_{2} \mathrm{O}_{3} \\
\text { molar ratio }\end{array}$} & \multirow{2}{*}{$S_{\mathrm{sp}}^{*}, \mathrm{~m}^{2} / \mathrm{g}$} & \multicolumn{2}{|c|}{$\begin{array}{l}\text { Equilibrium vapor adsorption } \\
\text { capacities, } \mathrm{cm}^{3} / \mathrm{g}\end{array}$} & \multicolumn{3}{|c|}{ 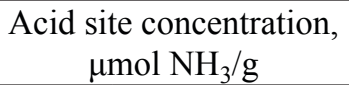 } \\
\hline & & & & $\mathrm{H}_{2} \mathrm{O}$ & $\mathrm{C}_{6} \mathrm{H}_{6}$ & $C_{\mathrm{I}}$ & $C_{\mathrm{II}}$ & $C_{\text {total }}$ \\
\hline $0.62 \mathrm{NaH}-\mathrm{Y}$ & 97 & 5 & 725 & 0.30 & 0.33 & 772 & 528 & 1316 \\
\hline $0.97 \mathrm{H}-\mathrm{Y}$ & 90 & 5 & 725 & 0.27 & 0.30 & 963 & 548 & 1511 \\
\hline H-MOR & 98 & 10 & 390 & 0.16 & 0.18 & 634 & 315 & 949 \\
\hline H-Beta(18) & 97 & 18 & 470 & 0.30 & 0.30 & 530 & 340 & 870 \\
\hline H-Beta(40) & 98 & 40 & 726 & 0.30 & 0.30 & 448 & 307 & 755 \\
\hline H-ZSM-5 & 98 & 38 & 312 & 0.14 & 0.19 & 421 & 242 & 663 \\
\hline H-ZSM-12 & 97 & 34 & 320 & 0.14 & 0.18 & 409 & 280 & 689 \\
\hline
\end{tabular}

${ }^{a} S_{\mathrm{sp}}^{*}$ is the BET specific surface area; $C_{\mathrm{I}}, C_{\mathrm{II}}, C_{\text {total }}$ are the weak acid site, strong acid site, and total acid site concentration, respectively.

70v Fourier transform IR spectrometer in $\mathrm{KBr}$ tablets. ${ }^{1} \mathrm{H}$ and ${ }^{13} \mathrm{C}$ NMR spectra were recorded on a Bruker AVANCE-400 spectrometer with operating frequency $400.13 \mathrm{MHz}$ for ${ }^{1} \mathrm{H}$ nuclei and $100.62 \mathrm{MHz}$ for ${ }^{13} \mathrm{C}$ nuclei in standard $5 \mathrm{~mm}$ diameter ampoules for $\mathrm{CDCl}_{3}$ solutions. Benzene- $d_{6}$, toluene- $d_{8}$ were used as internal standards. High resolution mass spectra were recorded on a Shimadzu instrument in which a chromatograph was equipped with a SPB-5 60 m capillary column.

The catalyst activity was estimated by the total $\mathrm{C}_{5}$ olefin conversion rate, $X(\%)$ :

$$
X=\frac{\left[C\left(\mathrm{C}_{5}^{=}\right)_{0}-C\left(\mathrm{C}_{5}^{=}\right)_{\mathrm{t}}\right]}{C\left(\mathrm{C}_{5}^{ \pm}\right)_{0}} \times 100
$$

where $C\left(\mathrm{C}_{5}^{=}\right)_{0}$ and $C\left(\mathrm{C}_{5}^{=}\right)_{\mathrm{t}}$ are the $\mathrm{C}_{5}$ olefin concentrations before and after the reaction, respectively.

The selectivity (\%) and yield (\%) of the amylene oligomerization products were estimated by the following formulas:

$$
\begin{gathered}
S_{i}=\frac{C_{i} \times 100}{\left[100-C\left(\mathrm{C}_{5}\right)\right]}, \\
\gamma_{i}=\frac{S_{i} X}{100},
\end{gathered}
$$

where $C_{i}, S_{i}$, and $\gamma_{i}$ are the concentration in the reaction mixture, the selectivity, and the yield, respectively, of a single oligomerization product fraction (i.e., dimers, trimers, oligomers $n \geq 4$, or oligomers of cracking products); and $C\left(\mathrm{C}_{5}\right)$ is the concentration of $\mathrm{C}_{5}$ hydrocarbons in the reaction mixture.

\section{RESULTS AND DISCUSSION}

Physicochemical properties of catalysts. The physicochemical properties of the assayed zeolite samples are summarized in Table 2.

In accordance with the X-ray fluorescence (XRF) data and the equilibrium adsorption capacities for $\mathrm{H}_{2} \mathrm{O}$ and $\mathrm{C}_{6} \mathrm{H}_{6}$ vapors, all of the zeolites have a crystallinity of near $100 \%$.
The acidic properties of the zeolite samples were examined by $\mathrm{NH}_{3}-\mathrm{TPD}$. Two peaks are observed in the $\mathrm{NH}_{3}-\mathrm{TPD}$ spectra of zeolites: a low-temperature peak with a maximum in the region of $250-300^{\circ} \mathrm{C}$ and a high-temperature peak with a maximum in the region of $410-480^{\circ} \mathrm{C}$. This evidences the presence of two acid site types in the samples: weak acid sites corresponding to the low-temperature peak, and strong acid sites corresponding to the high-temperature peak. The total concentration of acid sites reaches its maximum in $\mathrm{H}-\mathrm{Y}$ zeolite. When shifting to higher-silica molecular sieves, it decreases in the following order: $\mathrm{H}-\mathrm{MOR}>\mathrm{H}-\mathrm{Beta}(18)>$ $\mathrm{H}-\mathrm{Beta}(40)>\mathrm{H}-\mathrm{ZSM}-12>\mathrm{H}-\mathrm{ZSM}-5$. The concentration of strong acid sites, which are the most important for catalytic conversions, displays the following trend: $\mathrm{H}-\mathrm{Y}>$ H-Beta(18) > H-MOR $>$ H-Beta(40) $>$ H-ZSM-12 > H-ZSM-5.

Catalytic properties of zeolite catalysts in amylene oligomerization. The reaction mixture obtained from amylene oligomerization contains amylenes, their oligomers (dimers, trimers, and higher molecular compounds), as well as $\mathrm{C}_{6}-\mathrm{C}_{9}$ and $\mathrm{C}_{11}-\mathrm{C}_{14}$ olefins resulting from the destruction of amylene oligomers and subsequent oligomerization of cracking products. These compounds are referred to herein as OCP. The general mechanism of isoamylene conversions, which includes three main pathways, namely isomerization, oligomerization, and cracking, is illustrated on Scheme 1.

The effects of the zeolite structure type on isoamylene conversion rate and product selectivity are graphically illustrated in Fig. 1.

Under the above conditions $\left(110^{\circ} \mathrm{C}, 10 \mathrm{wt} \%\right.$ of catalyst, $5 \mathrm{~h}$ ), the highest total isoamylene conversion rate was observed with $\mathrm{H}-\mathrm{MOR}$ and decreased in the following order: $\mathrm{H}-\mathrm{MOR}>\mathrm{H}-\mathrm{Y}>\mathrm{H}-\mathrm{Beta}(40)>>$ H-ZSM-12 $>$ H-ZSM-5. The first three of the listed 
Scheme 1. Isoamylene conversions over zeolite catalysts.

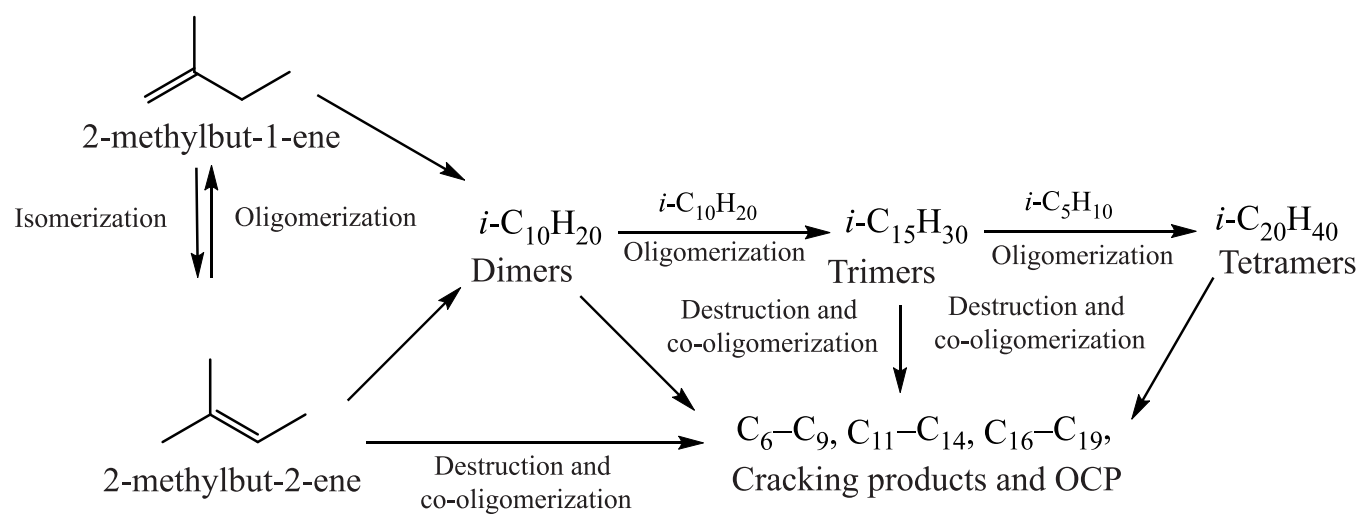

samples, namely H-MOR, H-Y, and H-Beta(40), represent wide-pore zeolites and have the highest concentration of acid sites (Table 1), which is likely to account for their high activity in the reaction. Because all of the reactions shown on the schematic were observed in the presence of these three catalysts, the products contained unreacted isoamylenes, isoamylene oligomers, and OCP. In contrast, hardly any OCP were formed over pentasyls, i.e., H-ZSM-12 and H-ZSM5 . The oligomers, formed over all the zeolites except $\mathrm{H}-\mathrm{ZSM}-5$, contained dimers and trimers of isoamylenes. Isoamylene oligomerization over $\mathrm{H}-\mathrm{ZSM}-5$ gave rise solely to decenes.

Thus, the highest activity in isoamylene oligomerization was demonstrated by wide-pore zeolites H-MOR,
$\mathrm{H}-\mathrm{Beta}(40)$, and $\mathrm{H}-\mathrm{Y}$, which have a high concentration of acid sites. These zeolites exhibited the maximum yields of isoamylene oligomers, from $79.8 \%$ over $\mathrm{H}-\mathrm{Beta}(40)$ to $85.0 \%$ over H-MOR (Table 3 ).

As might be expected, the activity of $\mathrm{H}-\mathrm{Y}, \mathrm{H}-\mathrm{MOR}$, and $\mathrm{H}-\mathrm{Beta}(40)$ is not limited to the oligomerization reaction alone. These zeolites promote intense cracking of isoamylenes and newly-formed oligomers even at $110^{\circ} \mathrm{C}$. The OCP yield is the highest $(9.9 \%)$ over $\mathrm{H}-\mathrm{Y}$. Given that OCP are also produced from oligomerization (of lighter compounds rather than isoamylenes), the total oligomer yield can be estimated as the sum of the yields of isoamylene oligomers and OCP (Table 3 ). In this case, the highest total oligomer yields were achieved over $\mathrm{H}-$

(a)

(b)

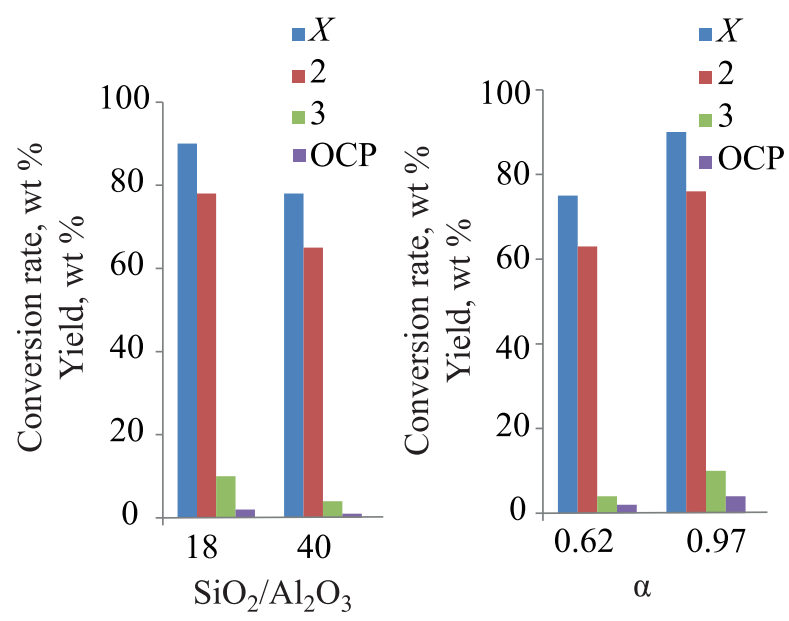

Fig. 2. (a) Isoamylene oligomerization over $\mathrm{H}-\mathrm{Beta}$ with a $\mathrm{SiO}_{2} / \mathrm{Al}_{2} \mathrm{O}_{3}$ molar ratio of 18 and $40\left(80^{\circ} \mathrm{C}, 10 \mathrm{wt} \%\right.$ catalyst, $5 \mathrm{~h}$ ) and (b) isoamylene oligomerization over $\mathrm{H}-\mathrm{Y}$ with a $\mathrm{Na}^{+} / \mathrm{H}^{+}$ion exchange degree $(\alpha)$ of 0.62 and $0.97\left(60^{\circ} \mathrm{C}\right.$, 10 wt \%catalyst, $5 \mathrm{~h})$. $(X)$ conversion rate; $(2)$ dimers; (3) trimers; and (OCP) cracking products and oligomers of cracking products.
Fig. 1. Amylene conversion rate $(X)$ and composition of reaction products as functions of zeolite structure type: (2) dimers; (3) trimers; (OCP) cracking products and oligomers of cracking products. Reaction conditions: $110^{\circ} \mathrm{C}$, $10 \mathrm{wt} \%$ catalyst, $5 \mathrm{~h}$. 
Table 3. Product yields and dimer/trimer ratio vs. zeolite structure type ${ }^{\mathrm{a}}$

\begin{tabular}{l|r|r|c|c|c}
\hline \multicolumn{1}{c|}{ Parameter } & \multicolumn{5}{c}{ Catalyst } \\
\cline { 2 - 6 } & H-Y & H-MOR & H-Beta (40) & H-ZSM-12 & H-ZSM-5 \\
\hline iso-C Fligomer yield, \% $_{\text {OCP yield, \% }}^{80.1}$ & 9.9 & 85.0 & 79.8 & 30.2 & 17.4 \\
Total C $6-C_{15}$ oligomer yield, \% & 90.0 & 92.3 & 3.2 & 0.1 & N/D \\
Dimer/trimer & 8.2 & 6.5 & 83.0 & 30.4 & 17.4 \\
\hline
\end{tabular}

${ }^{a}$ Reaction conditions: $110^{\circ} \mathrm{C}, 10 \mathrm{wt} \%$ catalyst, $5 \mathrm{~h}$.

MOR (92.3\%) and, at a slightly lower level, over H-Y (90.0\%) and $\mathrm{H}-\mathrm{Beta}(40)(83.0 \%)$.

It should be noted that dimers predominate in the isoamylene oligomers regardless of the zeolite type (Table 3). The highest yield of trimers is ensured by wide-pore zeolites, as evidenced by dimer/trimer ratios of 6.7 to 13.3 when the H-MOR, H-Y, and H-Beta(40) samples were tested. H-ZSM-12 minimizes the trimer yield and, as mentioned above, $\mathrm{H}-\mathrm{ZSM}-5$ prevents any trimer formation under the assayed conditions.

The ${ }^{1} \mathrm{H},{ }^{13} \mathrm{C}$, and DEPT 135 NMR examination of the chemical structure of the oligomers obtained in the presence of $\mathrm{H}-\mathrm{Beta}(18)$ indicated that the dimers are mainly composed of 3,5,5-trimethyl-hept-2-ene, 3,4,5,5-tetramethyl-hex-2-ene, 2,3,4,4-tetramethyl-hex1 -ene, and 3,4,4,5-tetramethyl-hex-2-ene. The formation of the same isodecenes is reported in $[4,5]$. The trimers produced at $60^{\circ} \mathrm{C}$ comprise a mixture of primarily two compounds: (4E)-3,3,5,6,7,7-hexamethyl-non-4-ene and 3,3,4,7,7-pentamethyl-5-methylidene-nonane.

The high importance of the concentration of acid sites and their influence on the activity and selectivity of zeolite catalysts in isoamylene oligomerization was demonstrated by an example of $\mathrm{H}$-Beta samples having different $\mathrm{SiO}_{2} / \mathrm{Al}_{2} \mathrm{O}_{3}$ molar ratios (18 and 40) and by another example of $\mathrm{H}-\mathrm{Y}$ samples differing in decationation degree $(\alpha=0.62$ and 0.97$)$ (Fig. 2).

The catalytic properties of H-Beta(18) vs. H-Beta(40) evidence the lower reactivity of the latter zeolite, which has a smaller concentration of acid sites (Table 2). Using $\mathrm{H}-\mathrm{Beta}(40)$ at $80^{\circ} \mathrm{C}$, isoamylene conversion rate was almost $20 \%$ lower than in the $\mathrm{H}-\mathrm{Beta}(18)$ case. The total oligomer yield in the presence of $\mathrm{H}-\mathrm{Beta}(40)$ was approximately 1.2 times lower than with $\mathrm{H}-\mathrm{Beta}(18)$. Furthermore, the oligomers have a considerably smaller proportion of trimers in the $\mathrm{H}-\mathrm{Beta}(40)$ case, as indicated by a dimer/trimer ratio estimate of 13.2, as compared to 6.2 for $\mathrm{H}-\mathrm{Beta}(18)$. The amount of OCP, although insignificant at $80^{\circ} \mathrm{C}$, is also higher for the more active H-Beta(18).
Similar relationships were observed in the $\mathrm{H}-\mathrm{Y}$ samples that had a different $\mathrm{Na}^{+} / \mathrm{H}^{+}$ion exchange degree $(\alpha), 0.62$ and 0.97 (Fig. 2b). A higher decationation degree of $\mathrm{H}-\mathrm{Y}$ zeolite corresponds to a higher acid site concentration (Table 2) and, in turn, to an enhanced catalyst activity in isoamylene oligomerization and to an increased oligomer yield (Fig. 2b). The higher acid site concentration increases the oligomerization degree, which is reflected in a smaller proportion of dimers in the oligomer fraction over the $0.97 \mathrm{H}-\mathrm{Y}$ sample (dimer/trimer =

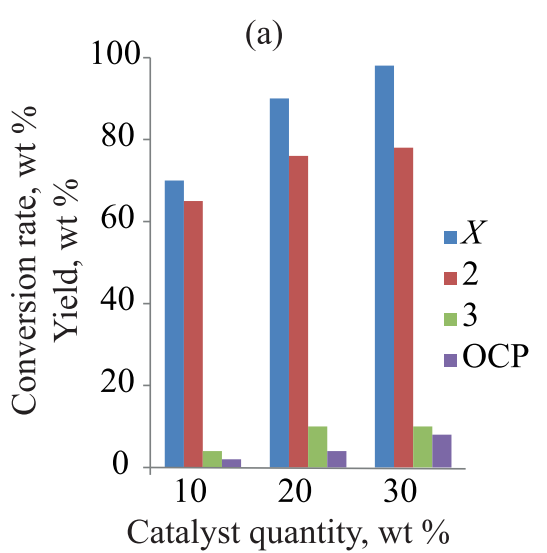

(b)

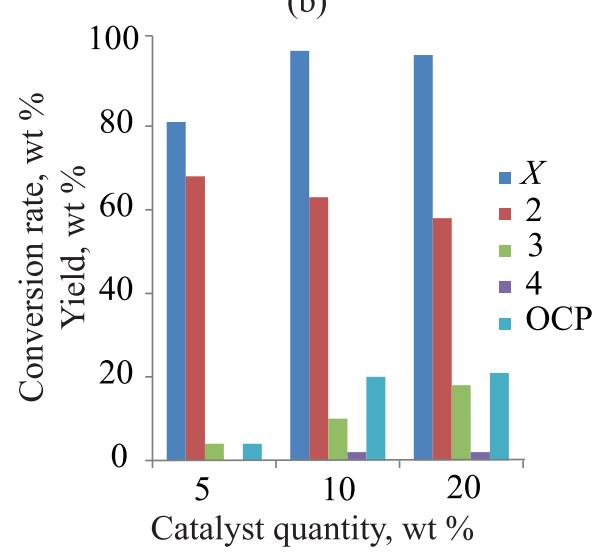

Fig. 3. Amylene conversion rate and composition of reaction products as functions of catalyst quantity. Reaction conditions: (a) $60^{\circ} \mathrm{C}, 10-30 \mathrm{wt} \% \mathrm{H}-$ Beta $(40), 5 \mathrm{~h}$ and (b) $150^{\circ} \mathrm{C}, 5-$ 20 wt \% H-Beta (40), 5 h. $(X)$ conversion rate; (2) dimers; (3) trimers; (4) oligomers $n \geq 4$; and (OCP) cracking products and oligomers of cracking products. 


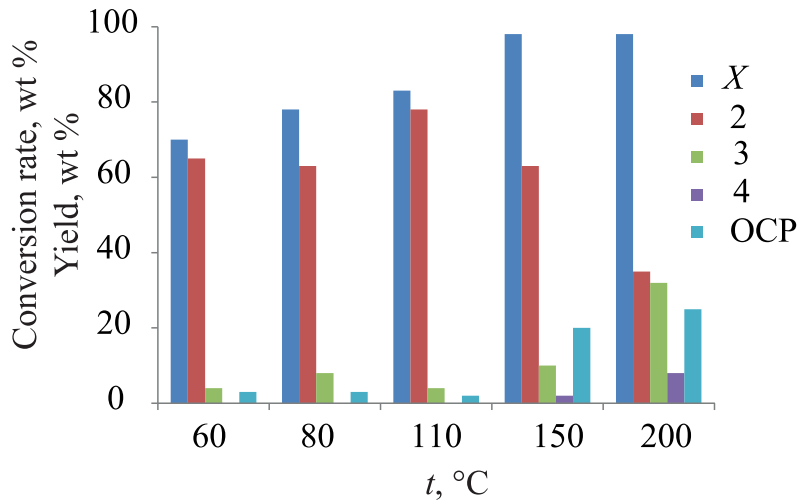

Fig. 4. Amylene conversion rate and composition of reaction products as temperature functions. Reaction conditions: $60-20{ }^{\circ} \mathrm{C}, 10 \mathrm{wt} \% \mathrm{H}-$ Beta $(40), 5$ h. $(X)$ conversion rate; (2) dimers; (3) trimers; (4) oligomers $n \geq 4$; and (OCP) cracking products and oligomers of cracking products.

6.8) than over $0.62 \mathrm{HNaY}($ dimer/trimer $=14.9)$. The OCP yield was higher with the more acidic and deeply decationed $0.97 \mathrm{H}-\mathrm{Y}$ sample.

When examining the effect of reaction conditions (temperature and catalyst quantity) on isoamylene conversion in the presence of $\mathrm{H}-\mathrm{Beta}(40)$, it was found that the monomer conversion rate grows with an increase in temperature and catalyst concentration (Figs. 3 and 4). While $30 \mathrm{wt} \%$ of the catalyst is required to achieve a substantially complete amylene conversion at low temperature $\left(60^{\circ} \mathrm{C}\right)$, a high monomer conversion rate at $150^{\circ} \mathrm{C}$ is achieved in the presence of as low as $10 \%$ of the catalyst. The oligomer yield displays an extreme trend in the temperature range of 60 to $200^{\circ} \mathrm{C}$ with a maximum at $110^{\circ} \mathrm{C}$.

The oligomer yield decline with temperature elevation above $110^{\circ} \mathrm{C}$ is associated with a noticeable amount of OCP in the products. For example, the OCP yield is $4 \%$ at $110^{\circ} \mathrm{C}, 21 \%$ at $150^{\circ} \mathrm{C}$, and $27 \%$ at $200^{\circ} \mathrm{C}$. The temperature elevation also leads to a decline in dimer proportion, a growth in trimer proportion, and the appearance of tetramers in the oligomer fraction.

The functional relationship between the product composition and the catalyst quantity significantly depends on the oligomerization temperature. At $60^{\circ} \mathrm{C}$, the yields of isoamylene dimers and trimers grow as the catalyst concentration increases from 10 to $30 \%$. At the same time, the quantity of destruction products rises from 1 to $5 \%$. However, the oligomer yield follows the reverse trend at $150^{\circ} \mathrm{C}$ : the yield declines as the catalyst quantity increases from 5 to $20 \%$. The OCP yield is 5 to 12 times higher at $150^{\circ} \mathrm{C}$ than at $60^{\circ} \mathrm{C}$.

\section{CONCLUSIONS}

Based on the study of isoamylene oligomerization over various microporous zeolites such as $\mathrm{H}-\mathrm{Y}, \mathrm{H}-\mathrm{MOR}$, $\mathrm{H}-\mathrm{Beta}, \mathrm{H}-\mathrm{ZSM}-12$, and $\mathrm{H}-\mathrm{ZSM}-5$, it was found that isoamylenes readily dimerize under mild conditions $\left(60-150^{\circ} \mathrm{C}, 10 \mathrm{wt} \%\right.$ catalyst). The highest activity in oligomerization was demonstrated by $\mathrm{H}-\mathrm{Y}, \mathrm{H}-\mathrm{MOR}$, and $\mathrm{H}-\mathrm{Beta}$, which ensured an amylene conversion rate up to $83-95 \%$ (at $110^{\circ} \mathrm{C}$ ). The same samples exhibited the highest yields of isoamylene oligomers: $79.8 \%$ with $\mathrm{H}-\mathrm{Beta}(40), 80.1 \%$ with $\mathrm{H}-\mathrm{Y}$, and $85.0 \%$ with $\mathrm{H}-\mathrm{MOR}$.

It was demonstrated, by examples of $0.62 \mathrm{NaH}-\mathrm{Y}$, $0.97 \mathrm{H}-\mathrm{Y}, \mathrm{H}-\mathrm{Beta}(40)$, and $\mathrm{H}-\mathrm{Beta}(18)$, that acid site concentration growth enhances the zeolite activity in oligomerization and increases the yield and the molecular weight of oligomers produced.

The conditions for producing amylene oligomers with maximum yield over $\mathrm{H}-\mathrm{Beta}(40)$ have been determined to be: $60^{\circ} \mathrm{C}$ and $30 \mathrm{wt} \%$ catalyst for production of dimers (79\%); $200^{\circ} \mathrm{C}$ and $10 \mathrm{wt} \%$ catalyst for production of trimers and tetramers (31 and 8\%, respectively). Elevating the temperature and catalyst concentration above these values adds to the destruction of newly-formed oligomers, thus reducing oligomer yield.

Using chromatography-mass spectrometry, IR, ${ }^{1} \mathrm{H}$ NMR and ${ }^{13} \mathrm{C}$ spectroscopy, and ${ }^{13} \mathrm{C}$ DEPT, the structures of the resulting decenes and pentadecenes were determined.

\section{AUTHOR INFORMATION}

N.G. Grigor'eva, ORCID: http://orcid.org/0000-00016451-9205

D.V. Serebrennikov, ORCID: http://orcid.org/0000-00026601-390X

S.V. Bubennov, ORCID: http://orcid.org/0000-0002-2230$772 \mathrm{X}$ 5510

B.I. Kutepov, ORCID: http://orcid.org/0000-0003-0745-

\section{FUNDING}

The study described here was performed with financial support from the Ministry of Education and Science of the Russian Federation, Federal Target Program (grant no. 201905-595-000-058), using equipment of the Agidel Center for Collective Use, Ufa Federal Research Center, Russian Academy of Sciences (IPC UFRC RAS), Ufa, Russia.

\section{CONFLICT OF INTEREST}

The authors declare no conflict of interest requiring disclosure in this article.

PETROLEUM CHEMISTRY Vol. 61 No. 22021 


\section{OPEN ACCESS}

This article is distributed under the terms of the Creative Commons Attribution 4.0 International License (http:// creativecommons.org/licenses/by/4.0/), which permits unrestricted use, distribution, and reproduction in any medium, provided you give appropriate credit to the original author(s) and the source, provide a link to the Creative Commons license, and indicate if changes were made.

\section{REFERENCES}

1. Ipatieff, V.N., Indust. Eng. Chem., 1935, vol. 27, no. 9, pp. 1067-1071.

https://doi.org/10.1021/ie50309a024

2. Davis, M.E., AlChE J., 1991, vol. 37, no. 2, p. 310. https://doi.org/10.1002/aic.690370223

3. Shah, N.F. and Sharma, M.M., React. Funct. Polym., 1993, vol. 19, pp. 181-190. https://doi.org/10.1016/0923-1137(93)90076-R

4. Marchionna, M., Girolamo, M.D., and Patrini, R., Catal. Today, 2001, vol. 65, pp. 397-403. https://doi.org/10.1016/S0920-5861(00)00587-3

5. Cruz, V.J., Izquierdo, J.F., Cunill, F., Tejero, J., Iborra, M., and Fité, C., React. Funct. Polym., 2005, vol. 65, pp. 149-160.

https://doi.org/10.1016/j.reactfunctpolym.2005.01.011

6. Cruz, V.J., Bringué, R., Cunill, F., Izquierdo, J.F., Tejero, J., Iborra, M., and Fité, C., J. Catal., 2006, vol. 238, no. 2, pp. 330-341.

https://doi.org/10.1016/j.jcat.2005.12.019

7. Cruz, V.J., Izquierdo, J.F., Cunill, F., Tejero, J., Iborra, M., Fité, C., and Bringue, R., React. Funct. Polym., 2007, vol. 67, pp. 210-224.

https://doi.org/10.1016/j.reactfunctpolym.2006.11.003

8. Granollers, M., Izquierdo, J.F., Tejero, J., Iborra, M., Fité, C., Bringue, R., and Cunill, F., Ind. Eng. Chem. Res., 2010, vol. 49, pp. 3561-3570. https://doi.org/10.1021/ie901382p

9. Granollers, M., Izquierdo, J.F., and Cunill F., Appl. Catal. A: General, 2012, volы. 435-36, pp. 163-171. https://doi.org/10.1016/j.apcata.2012.05.051

10. Granollers, M., Izquierdo, J.F., Fité, C., and Cunill, F., Chem. Eng. J., 2013, vol. 234, pp. 266-275. https://doi.org/10.1016/j.cej.2013.08.083

11. Schmidt, R., Welch, R.B., and Randolph, B.B., Energy and Fuels, 2008, vol. 22, no. 2, pp. 1148-1155. https://doi.org/10.1021/ef800005v

12. Bellussi, G., Mizia, F., Calemma, V., Pollesel, P., and Millini, R., Micropor. Mesopor. Mater., 2012, vol. 164, pp. 127-134. https://doi.org/10.1016/j.micromeso.2012.07.020

13. Krivan, E., Tomasek, S., and Hancsók, J., Period. Polytech. Chem. Eng., 2014, vol. 58, pp. 149-156.

https://doi.org/10.3311/PPch.7204 